\title{
Development of Conformational Antibodies to Detect Bcl-xL's Amyloid Aggregates in Metal-Induced Apoptotic Neuroblastoma Cells
}

\author{
Alexis Gonneaud ${ }^{1,2,+}$, Fatima-Zohra Fakhir ${ }^{1,3,+}{ }^{\oplus}$, Emeline Landas ${ }^{1}$, Enora Le Tallec ${ }^{1}$, \\ Elisabeth Chartier-Garcia ${ }^{1}$, Christine Almunia ${ }^{4}$, Alexandre Chenal ${ }^{5} \oplus$, Vincent Forge ${ }^{1}$ \\ and Christel Marquette $1, *$ (i) \\ 1 Laboratoire de Chimie et Biologie des Métaux, UMR5249 Université Grenoble Alpes, CNRS, CEA, \\ 17 rue des Martyrs, CEDEX 9, 38054 Grenoble, France; alexis.gonneaud@usherbrooke.ca (A.G.); \\ fatimazohra.fakhir@gmail.com (F.-Z.F.); emeline66@hotmail.fr (E.L.); enora.letallec@yahoo.fr (E.L.T.); \\ Elisabeth.CHARTIER-GARCIA@cea.fr (E.C.-G.); vincent.forge@cea.fr (V.F.) \\ 2 Département d'immunologie et biologie cellulaire, Pavillon de recherche appliquée sur le cancer, Faculté de \\ médecine et des sciences de la santé, Université de Sherbrooke, Sherbrooke, QC J1E 4K8, Canada \\ 3 Faculté des Sciences d'El Jadida, Université Chouaib Doukkali, El Jadida 24000, Maroc \\ 4 Laboratory «Innovative Technologies for Detection and Diagnostics» CEA-Marcoule, DRF-Li2D PRAE \\ Marcel Boiteux, BP 1717, 30200 Bagnols-sur-Cèze CEDEX, France; christine.almunia@cea.fr \\ 5 Chemistry and Structural Biology Department, Institut Pasteur, UMR CNRS 3528, CEDEX 15, \\ 75724 Paris, France; alexandre.chenal@pasteur.fr \\ * Correspondence: christel.marquette@cea.fr \\ + These authors contributed equally to this work.
}

Received: 4 September 2020; Accepted: 10 October 2020; Published: 15 October 2020

\begin{abstract}
Bcl-xL, a member of the Bcl-2 family, is a pro-survival protein involved in apoptosis regulation. We have previously reported the ability of Bcl-xL to form various types of fibers, from native to amyloid conformations. Here, we have mimicked the effect of apoptosis-induced caspase activity on Bcl-xL by limited proteolysis using trypsin. We show that cleaved Bcl-xL $(\Delta \mathrm{N}-\mathrm{Bcl}-\mathrm{xL})$ forms fibers that exhibit the features of amyloid structures (BclxLcf37). Moreover, three monoclonal antibodies (mAbs), produced by mouse immunization and directed against $\Delta \mathrm{N}-\mathrm{Bcl}-\mathrm{xL}$ or Bcl-xL fibers, were selected and characterized. Our results show that these mAbs specifically target $\Delta \mathrm{N}-\mathrm{Bcl}-\mathrm{xL}$ in amyloid fibers in vitro. Upon metal-stress-induced apoptosis, these mAbs are able to detect the presence of Bcl-xL in amyloid aggregates in neuroblastoma SH-SY5Y cell lines. In conclusion, these specific $\mathrm{mAbs}$ directed against amyloidogenic conformations of $\mathrm{Bcl}-\mathrm{xL}$ constitute promising tools for studying, in vitro and in cellulo, the contribution of Bcl-xL in apoptosis. These mAbs may further help in developing new diagnostics and therapies, considering Bcl-xL as a strategic target for treating brain lesions relevant to stroke and neurodegenerative diseases.
\end{abstract}

Keywords: Bcl-xL; apoptosis; oxidative stress; amyloid fibers

\section{Introduction}

Within neurodegenerative diseases, e.g., Alzheimer's disease (AD) or stroke-induced ischemia, multiple and complex molecular events are implicated in critical processes, such as oxidative stress, protein aggregation, and mitochondrial dysfunctions. In these pathologies, biometals play a major role in the initiation and development of lesions. They are essential elements for life that play crucial roles in healthy organs and tissue functions, such as the brain's neurotransmitter synthesis, neural information processing, and neuronal myelination [1]. Consequently, the local dysregulation of their 
concentrations generates severe changes in critical biological systems, with the initiation of cascades of events leading to cell death. Increasing evidence suggests that transition-metal homeostasis, i.e., of iron, copper, and zinc, is dysregulated in neurodegenerative pathologies [2]. In fact, these transition metals are enriched in amyloid aggregates and facilitate the stimulation of the production of reactive oxygen species (ROS) [3-5]. In AD, such redox activity has been reported to be sustained by $A \beta$ amyloid fibrils, found in the brains of AD patients, and to promote local deleterious oxidative damage, and inflammation-mediated and apoptotic neuronal cell death [6]. In turn, oxidative stress and ROS contribute to $\mathrm{AD}$ pathophysiology by influencing the amyloid precursor protein's processing [7] and by exacerbating $A \beta$ aggregation $[8,9]$.

Apoptosis is an essential and critical physiological process for maintaining tissue integrity through normal homeostasis: a balance between cell proliferation and cell death. In a context of chronic ROS production, as described in slow-onset neurodegenerative diseases, this balance shifts in favor of apoptosis via chronic inflammation [10] and the dysfunction of mitochondria [11]. There are two main pathways for the induction of apoptosis: the death receptor (or extrinsic) pathway and the mitochondrial (or intrinsic) pathway. The mitochondrial pathway involves key players, the B-cell lymphoma 2 (Bcl-2) family members, which regulate apoptosis by balancing survival and cell death [12]. This protein family is classified into three groups depending on structural and functional properties: (a) pro-survival Bcl-2 proteins, including Bcl- 2, Bcl-xL, Mcl-1, and Bcl-w [13]; (b) pro-apoptotic effector proteins, i.e., Bax and Bak [14], which interact strongly with anti-apoptotic proteins [15]; and (c) BH3-only proteins, which convey signals to initiate apoptosis, including Bim, Puma, Bid, Bik, Bad, Bmf, Hrk, and Noxa [16]. In this family, Bcl-xL plays anti-apoptotic roles by preventing the oligomerization of the pro-apoptotic proteins Bax and Bak [17-22], reducing cytochrome c release [23-25], and regulating caspase activity [26,27]. In addition to its importance in cell survival, Bcl-xL is reported to play critical roles in neurophysiology by controlling intracellular energy metabolism and enhancing mitochondrial adenosine triphosphate (ATP) production $[28,29]$. Bcl-xL also promotes neurotransmission and synaptic vesicle endocytosis homeostasis [30] and neurite outgrowth and branching [31]. It prevents the loss of axons and dendrites during neurotoxic insults and supports proper synapse formation [30].

Moreover, the activity of the Bcl-xL protein is tightly controlled by interactions between the members and regulated by their post-translational modifications such as deamidation that can reverse Bcl-xL activities from anti- to pro-apoptotic [21]. Cell death processes stimulate the phosphorylation of $\mathrm{Bcl}-\mathrm{xL}$ and enable the activation of caspase cleavage [32], converting Bcl-xL to a pro-apoptotic protein mimicking the BCL-2 family of proteins such as Bax, Bid, and Bcl-2 [17,33-37]. Full length Bcl-xL protein contains a caspase cleavage site, producing a $\mathrm{C}$-terminal fragment that has Bax-like pro-apoptotic activity. The resulting protein (called $\Delta \mathrm{N}-\mathrm{Bcl}-\mathrm{xL}$ ) is thought to confer the cell protection against apoptosis [38,39]. It is likely that conformational rearrangements coincident with the removal of the $\mathrm{N}$-terminus segment contribute to the pro-apoptotic activity of the cleaved Bcl-xL protein, especially in the brain, where Bcl-xL is highly expressed [40] and is involved in various processes such as synaptic transmission [41]. In fact, $\Delta \mathrm{N}-\mathrm{Bcl}-\mathrm{xL}$ produces large conductance ion channel activity in the outer mitochondrial membrane and may induce cell death by contributing to the increase in the conductance of this membrane and the release of cytochrome c [38,39]. Moreover, the accumulation of $\Delta \mathrm{N}-\mathrm{Bcl}-\mathrm{xL}$ is associated with mitochondrial injury or neuronal injury in both in vitro and in vivo models of cerebral ischemia [39,42-44]: glutamate-mediated excitotoxicity and ischemic strokes enhance the formation of endogenous $\Delta \mathrm{N}-\mathrm{Bcl}-\mathrm{xL}$ in hippocampal neurons, promoting neuronal death [31,43]. All these modifications provide diverse roles for Bcl-xL during the lives of the nervous system's cells $[45,46]$, playing both anti-apoptotic and pro-survival cellular roles $[47,48]$, making Bcl-xL an essential protein in cell fate.

We have previously shown that recombinant $\mathrm{Bcl}-\mathrm{xL}$, depleted of its transmembrane segment located at the C-terminal end of the protein (called Bcl-xL- $\Delta \mathrm{TM}$ ) $[45,49,50]$, can undergo various types of aggregation depending on temperature: amyloid-like fibrils are obtained at $37^{\circ} \mathrm{C}$, or amyloid fibrils are formed at $70^{\circ} \mathrm{C}$ [51]. In cellulo, recombinant Bcl-xL- $\Delta \mathrm{TM}$, internalized in a human neuroblastoma cell line, SH-SY5Y, acquires biochemical modifications when the cells are exposed to stress with 
staurosporine. Bcl-xL- $\Delta \mathrm{TM}$ accumulates, aggregates, and exhibits amyloid features [51]. In this study, we mimicked the caspase cleavage of the N-terminal fragment of the loop domain (between Arg78Glu79) of Bcl-xL- $\Delta \mathrm{TM}$ with enzymatic proteolysis by trypsin, and we generated fragments after the incubation of the $\Delta \mathrm{N}-\mathrm{Bcl}-\mathrm{xL}-\Delta \mathrm{TM}$ under physiological conditions, i.e., at neutral $\mathrm{pH}$ and at $37^{\circ} \mathrm{C}$. We could monitor the formation of canonical amyloid fibers. We generated conformational and highly specific monoclonal antibodies (mAbs) by mouse immunization against $\Delta \mathrm{N}-\mathrm{Bcl}-\mathrm{xL}-\Delta \mathrm{TM}$ amyloid fibers (further called, in this study, BclxLcf37). Three mAbs were selected and characterized in cellulo, for studying the behavior of endogenous Bcl-xL in SH-SY5Y upon apoptotic cell death processes, i.e., those induced by transition-metal oxidative stress $(\mathrm{Cu}, \mathrm{Fe}$, and $\mathrm{Zn})$.

Such specific conformational antibodies against Bcl-xL amyloid fibers constitute powerful tools for identifying the different forms of $\mathrm{Bcl}-\mathrm{xL}$ implicated in the amyloid genesis of the apoptosis process. Regarding new therapies, c-mAbs might constitute specific tools for detecting and targeting Bcl-xL as a strategic protein target in brain injuries relevant to stroke or neurodegenerative diseases.

\section{Results}

\subsection{Trypsin Proteolysis of Bcl- $x L-\Delta T M$ Monomer Induces Its Conversion into Amyloid Fibrils}

Transmission electron microscopy pictures showed that the cleaved Bcl-xL- $\Delta \mathrm{TM}$ monomer was able to undergo fibril formation when incubated at $37^{\circ} \mathrm{C}$ (Figure $1 \mathrm{~A}$ ), and similarly to $\mathrm{A} \beta$. These fibers, labeled BclxLcf37, exhibit the tinctorial characteristics of amyloid fibrils, revealed by measuring ThT dye fluorescence (Figure 1B). After $24 \mathrm{~h}$ of incubation, a high difference in intensity was already measured between fibers formed with the entire native Bcl-xL- $\Delta \mathrm{TM}$ protein and the cleaved protein, $\Delta \mathrm{N}-\mathrm{Bcl}-\mathrm{xL}-\Delta \mathrm{TM}$, indicating a stronger amyloid feature for the fibers formed with the cleaved protein. Finally, the fluorescence of the Bcl-xL- $\Delta$ TM monomer showed a weaker signal than that of BclxLnf37, as described previously [51]. Overall, these results reveal that the formation of fibrils by the $\Delta \mathrm{N}-\mathrm{Bcl}-\mathrm{xL}-\Delta \mathrm{TM}$ is accompanied by profound conformational changes in the native structure, leading to the protein's aggregation into fibers with canonical amyloid features.

\subsection{Production, Selection, and Characterization of Conformational Antibodies Directed against BclxLcf37 (c-mAbs)}

Following immunized mouse ascites retrieval, selection by ELISA tests (Supplementary Table S1), and the fusion of hybridomas, three conformational monoclonal antibodies (c-mAbs) were isolated because of their specificity in recognizing only Bcl-xL in an amyloid conformation: $c-m A b$ J8-7, c-mAb B9-1, and c-mAb B3-9. Their specificity was tested using dot blot experiments with the three types of Bcl-xL fibers: Bclxlnf37 (low amyloid features), Bclxlnf70 (high amyloid features), and Bclxlcf37 (high amyloid features) (Figure 2 and Supplementary Table S2). Bcl-xL-fiber-specific recognition was addressed by comparing the signals of the c-mAbs J8-7, B3-9, and B9-1 with those obtained with commercial polyclonal and monoclonal antibodies. The J8-7 antibody recognized the three types of Bcl-xL fibers, with a stronger affinity for BclxLnf70 and a medium one for BclxLnf37 and BclxLcf37, and it did not recognize either monomeric Bcl-xL- $\Delta \mathrm{TM}$ or $\Delta \mathrm{N}-\mathrm{Bcl}-\mathrm{xL}-\Delta \mathrm{TM}$. By contrast, the B9-1 antibody recognized only BclxLnf70 with a medium affinity. The third c-mAb, B3-9, recognized, with a weak affinity, both fibers generated with native Bcl-xL. Among the three c-mAbs, only J8-7 also recognized, in a weaker fashion, $A \beta$ amyloid fibers. Thus, we generated three different conformational mAbs with different specificities: J8-7 recognizes the three Bcl-xL fibers and, particularly, the amyloid form, whereas B9-1 recognizes, more specifically, the amyloid form of native Bcl-xL fibers, and B3-9 recognizes native $\mathrm{Bcl}-\mathrm{xL}$ fibers. 

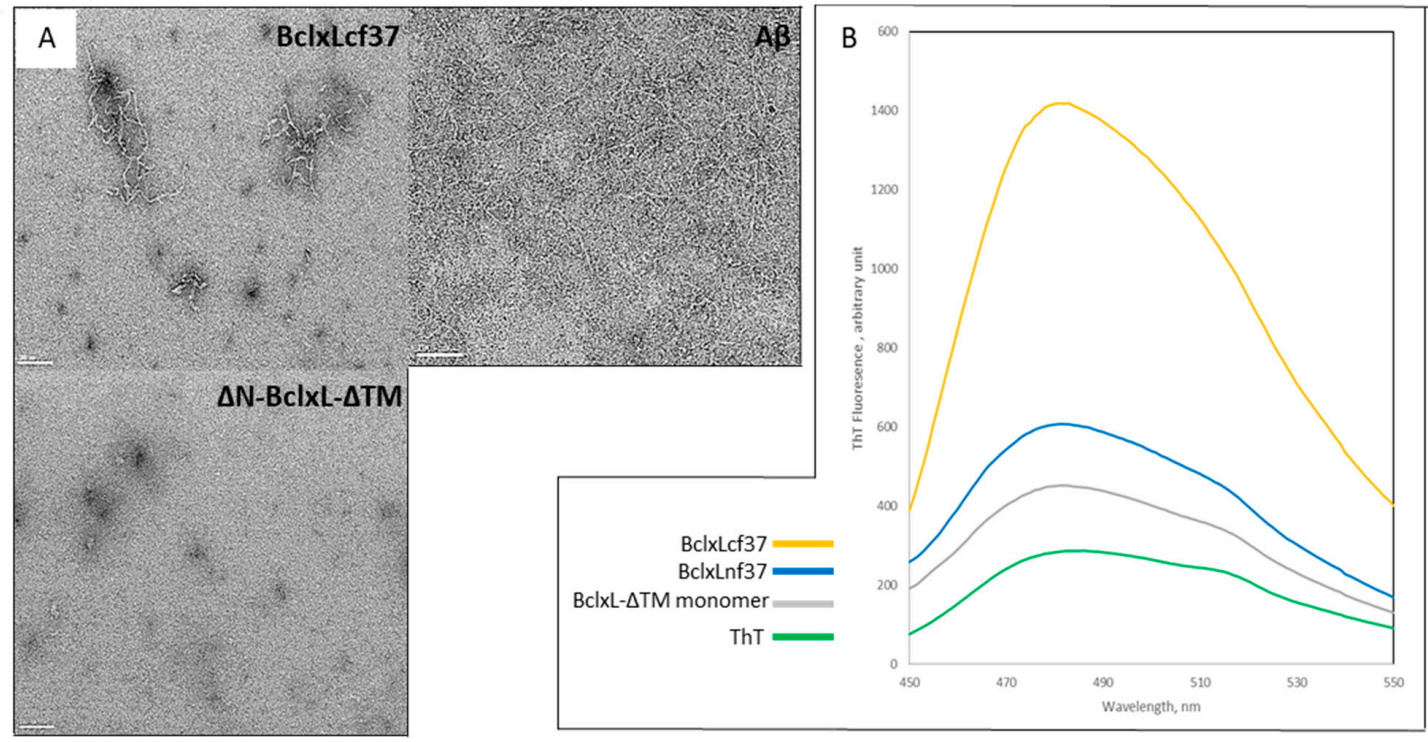

Figure 1. Trypsin-cleaved Bcl-xL forms amyloid fibers. (A) Transmission electron microscopy shows fibrils obtained from incubation of the cleaved Bcl-xL- $\Delta \mathrm{TM}$ form at $37^{\circ} \mathrm{C}$ (BclxLcf37); BclxLcf37 fibrils exhibit a similar shape to that of $A \beta$ fibrils, and with a completely different structure from the cleaved Bcl-xL- $\Delta$ TM monomer, which appears as an amorphous structure. Scale bar represent $100 \mu \mathrm{m}$ (B) BclxLcf37 fibrils present a high amyloid character as determined by Thioflavin-T fluorescence measurements: yellow curve represents results of fluorescence measurements of BclxLcl37 obtained from incubation of cleaved Bcl-xL- $\Delta \mathrm{TM}$ at $37^{\circ} \mathrm{C}$; blue curve represents results of fluorescence measurements of native and entire Bcl-xL fibers (BclxLnf37) obtained at $37^{\circ} \mathrm{C}$; gray curve represents results of fluorescence measurements of Bcl-xL- $\Delta \mathrm{TM}$ monomer; green curve represents results of fluorescence measurements of Thioflavin-T.

As expected, commercially available polyclonal antibodies $(\mathrm{pAb})$ recognized every form of Bcl-xL (native and cleaved monomer, and the three Bcl-xL fibers), whereas a commercial monoclonal antibody targeting the peptide encoding the sequence $3-14$ of $\mathrm{Bcl}-\mathrm{xL}\left(\mathrm{mAb}_{(3-14)}\right)$ recognized only the full form of $\mathrm{Bcl}-\mathrm{xL}-\Delta \mathrm{TM}$ (monomer and Bclxlnf37). Commercial Abs were unable to recognize $\mathrm{A} \beta$ fibers. It may be noted that $\mathrm{mAb}_{(3-14)}$ bound to $\Delta \mathrm{N}-\mathrm{Bcl}-\mathrm{xL}-\Delta \mathrm{TM}$ monomer very weakly and not to the cleaved $\mathrm{Bcl}-\mathrm{xL}$ fiber, BclxLcf37. This could be due to the fact that the cleaved monomer solution used for the dot blot, $\Delta \mathrm{N}-\mathrm{Bcl}-\mathrm{xL}-\Delta \mathrm{TM}$, contained all the fragments generated by the enzymatic trypsin cleavage. However, Bclxlcf37 was not recognized by $\mathrm{mAb}_{(3-14)}$, suggesting the absence of the $\mathrm{N}$-terminus in the fiber. 


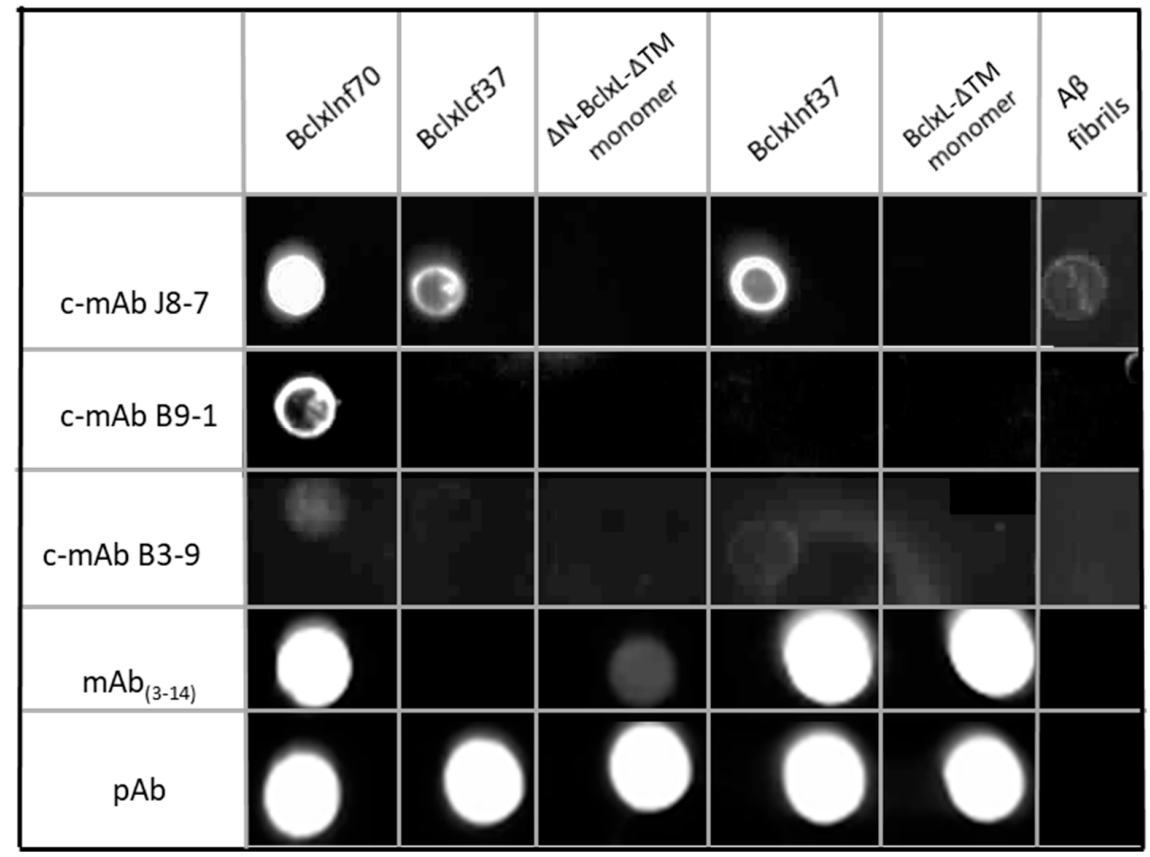

Figure 2. Amyloid specificity determined by dot blots: To test the specificity of c-mAbs J8-7, B9-1, and B3-9's immuno-recognition, $10 \mu \mathrm{g}$ of BclxLnf70, BclxLnf37, $\Delta \mathrm{N}-\mathrm{BclxL}-\Delta \mathrm{TM}$ monomer, BclxLcf37, BclxL- $\Delta \mathrm{TM}$ monomer, and $\mathrm{A} \beta$ fibers were spotted for dot blot immuno-detection. Controls were realized using commercial monoclonal $(\mathrm{mAb}(3-14))$ and polyclonal (pAb) anti-Bcl-xL antibodies.

\subsection{SH-SY5Y Cells as a Model to Monitor the Apoptosis Induced by Metal Stress}

The oxidative conditions induced by metal stress were confirmed by measuring the kinetics of the reactive oxidative species (ROS) production during the $24 \mathrm{~h}$ (Supplementary Figure S2). Copper led to a high and rapid response ( $88 \%$ compared to positive control, at $100 \%$, with $\mathrm{H}_{2} \mathrm{O}_{2}$ ) within the first $5 \mathrm{~h}$, which thereafter slowed down to $66 \%$ within $24 \mathrm{~h}$, whereas iron and zinc induced lower amounts of ROS, which reached $7 \%$ and $25 \%$, respectively, within $24 \mathrm{~h}$.

Cell death induced by iron, copper, and zinc was analyzed by flow cytometry assays using double staining with annexin V-PE and 7AAD antibodies (Figure 3). The results, expressed as percentages of cells labeled by annexin V-PE and/or 7AAD, show that iron, copper, and zinc stress, applied for $24 \mathrm{~h}$ to SH-SY5Y cells, mainly induced apoptosis: $23 \%$ of the cells for zinc (Figure 3C), 37.3\% of the cells for iron (Figure 3D), and 21\% of the cells for copper (Figure 3E) were in the early phase, and $75 \%$ of the cells for zinc, $61 \%$ of the cells for iron, and $78 \%$ of the cells for copper were already in the late apoptotic phase. $\mathrm{H}_{2} \mathrm{O}_{2}$ treatment (Figure 3B) constituted an efficient positive control to induce apoptosis at the end of cells' incubation: $87 \%$ of cells reached the late phase of apoptosis, and $12 \%$ were still in the early phase.

To support the characterization of the cell death process induced by metals, immunostaining with an antibody, anti-caspase-9, was carried out on cells incubated with (Figure 3F) or without metals (Figure 3G). Confocal images of the cells incubated with iron showed significant increases in red fluorescent staining (red dots) compared to in control cells, confirming caspase cascade activation related to apoptotic cell death. Apoptosis was also revealed by the appearance of nucleus bodies (blue spots, Hoechst staining), a classic morphological DNA fragmentation step representative of programmed cell death. Similar caspase-9 activation was observed in cells incubated with copper and zinc. 


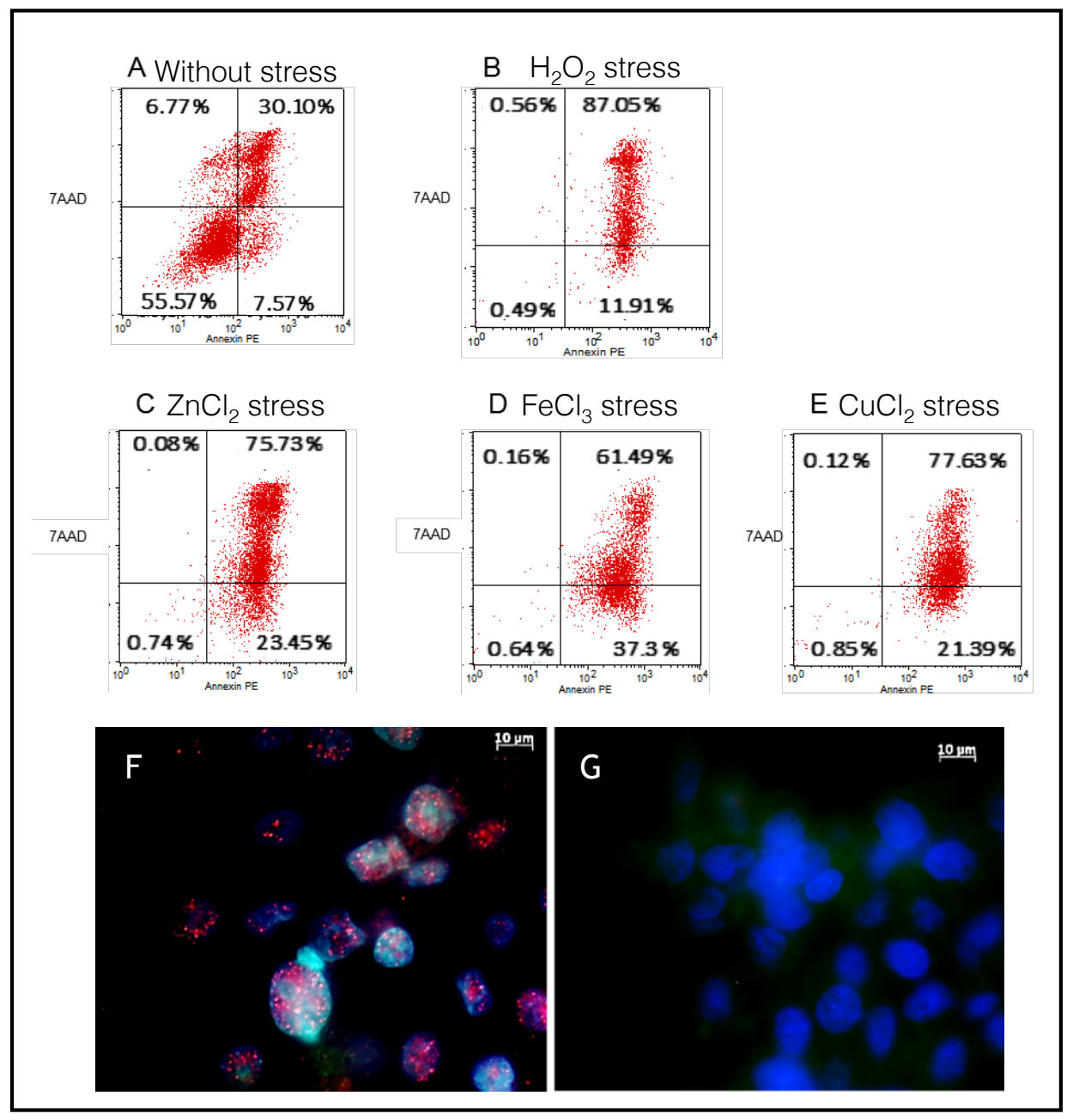

Figure 3. Metal stress-induced SH-SY5Y apoptosis. Annexin V-PE and 7AAD staining assay. Control experiments consisted of negative controls without stress (A) and positive controls with $\mathrm{H}_{2} \mathrm{O}_{2}$ stress $(100 \mu \mathrm{M})(\mathbf{B})$. FACS analysis of Annexin V-PE and 7AAD fluorescence signals in SH-SY5Y treated with $150 \mu \mathrm{M} \mathrm{ZnCl}_{2}$ (C), $300 \mu \mathrm{M} \mathrm{FeCl}_{3}$ (D), or $500 \mu \mathrm{M} \mathrm{CuCl}_{2}$ (E) for 24 h. Metal concentrations were selected based on the concentration-dependent death induced (see Supplementary Figure S1). Cells totally unlabeled represent alive cells; cells simply labeled with Annexin V-PE represent cells engaged in the early apoptosis phase; cells simply labeled with 7AAD represent cells engaged in the necrotic phase; cells double-labeled with Annexin V-PE and 7AAD represent cells engaged in late apoptotic and necrotic processes. Caspase-9 activation (F-G). (F) Caspase-9 immunostaining following $\mathrm{FeCl}_{3}$ $(300 \mu \mathrm{M})$ apoptotic stress induction (Alexa-594/caspase-9 antibody immunostaining); (G) SH-SY5Y without metal stress.

2.4. Endogenous Bcl-xL Is Converted into Amyloid Aggregates Following Apoptosis Induced by Metal Stress in SH-SY5Y Cells

The formation of amyloid fibrils by endogenous Bcl-xL was observed in metal-stressed SH-SY5Y cells. Cellular immunohistochemistry performed $24 \mathrm{~h}$ after metal stress (Figure 4) showed intracellular Bcl-xL whose specific antibody staining co-localized with thioflavin staining, used as a dye to identify amyloid fibrils. Immunochemistry pictures of cellular cultures incubated with different metals showed Bcl-xL, represented by red fluorescence, imaged at $\lambda=594 \mathrm{~nm}$ (Figure 4a,e,i), and ThT green fluorescent signals, imaged at $\lambda=488 \mathrm{~nm}$ (Figure $4 \mathrm{~b}, \mathrm{f}, \mathrm{j}$ ), which also co-localized within Bcl-xL deposits (Figure 4d,h,l, white arrows). Altogether, these results indicated that during the oxidative apoptotic process, cellular Bcl-xL underwent morphological changes, which led to its accumulation in amyloid aggregates. 


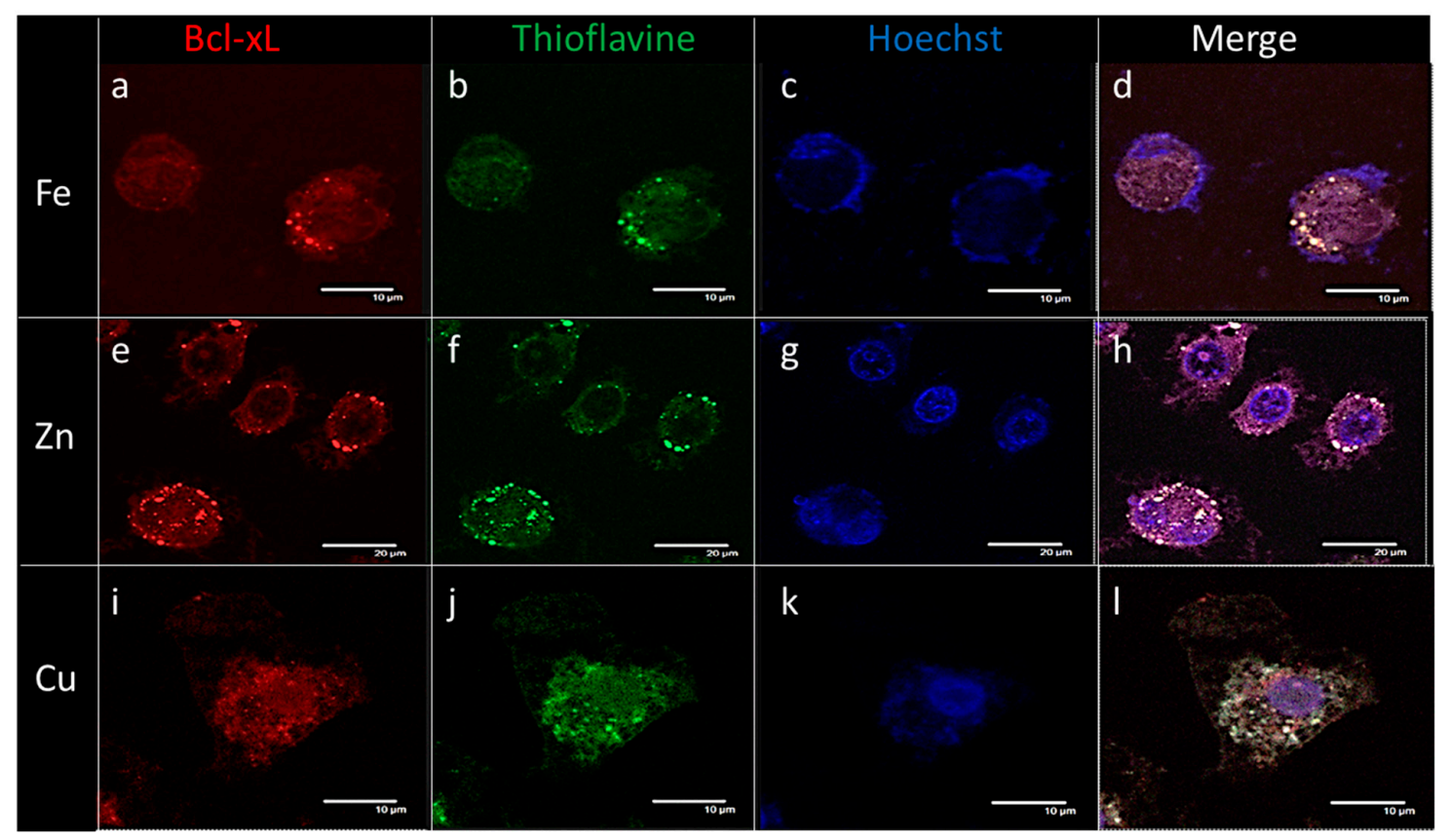

Figure 4. Metal stress-induced intracellular Bcl-xL amyloid deposits in SH-SY5Y: following iron (a-d), zinc (e-h), and copper (i-1) stress, immunostaining with commercial polyclonal anti-Bcl-xL antibodies and Thioflavin-T. Small white arrows indicate the same Bcl-xL aggregates recognized by the monoclonal antibody (a,e,i; visualized at $594 \mathrm{~nm}$, red color) and stained with the amyloid dye (b,f,j; visualized at $488 \mathrm{~nm}$, green color). Hoechst dye stained the nucleus (c,g,k; visualized at $405 \mathrm{~nm}$, blue color). Pictures $(\mathbf{d}, \mathbf{h}, \mathbf{l})$ resulted from the fluorescence merging of the three stains and reveal the co-localization of Bcl-xL aggregates with Thioflavin-T dye (white spots).

c-mAbs allow the immuno-detection of intracellular Bcl-xL amyloid aggregates following apoptosis induced by metal stress in SH-SY5Y cells : we then investigated if c-mAbs were suitable for both detecting Bcl-xL aggregates and characterizing these aggregates, in neuroblastoma cells under iron stress (Figure 5). In the control condition, i.e., without stress, we observed a weak and diffuse staining that was likely to be non-specific (Figure 5A,C,E,G). In the stressed condition, all the c-mAbs, B3-9, J8-7, and B9-1, detected aggregates, and their signals appeared in yellow, indicating an overlap between the two types of staining (yellow arrows), both ThT (green color, visualized at $488 \mathrm{~nm}$ ) and c-mAbs (red color, visualized at $594 \mathrm{~nm}$ ), indicating the presence of Bcl-xL in an amyloid conformation, as we described previously with the metal stress assay (Figure 4). For B9-1 (Figure 5D), the Ab recognizing the amyloid fibers of Bcl-xL only composed of the uncleaved protein, BclxLnf70 (Supplementary Table S2), we found a perfect overlap between the signals of immunostaining and ThT (yellow arrows). J8-7 and B3-9 (Figure 5F,H) recognized every type of Bcl-xL aggregate (Supplementary Table S2), and whereas some overlapping signals were still observed, some of the spots labeled with c-mAbs were not stained by ThT (red arrows). Therefore, these c-mAbs allowed the detection of coexisting amyloid and non-amyloid Bcl-xL aggregates within cell cultures. Moreover, association with ThT staining enabled discrimination between the two types of aggregates. B9-1 allowed probing the amyloid character of $\mathrm{Bcl}-\mathrm{xL}$ co-localizing with ThT staining and, further, the conclusion that $\mathrm{Bcl}-\mathrm{xL}$ was present within the amyloid deposits in an amyloid conformation and not simply as a native protein. Interestingly, we also observed in the SH-SY5Y cultures some aggregates stained with ThT (green arrow), indicating that these aggregates were amyloid but constituted by other types of protein, supporting the specificity of c-mAbs against Bcl-xL. 


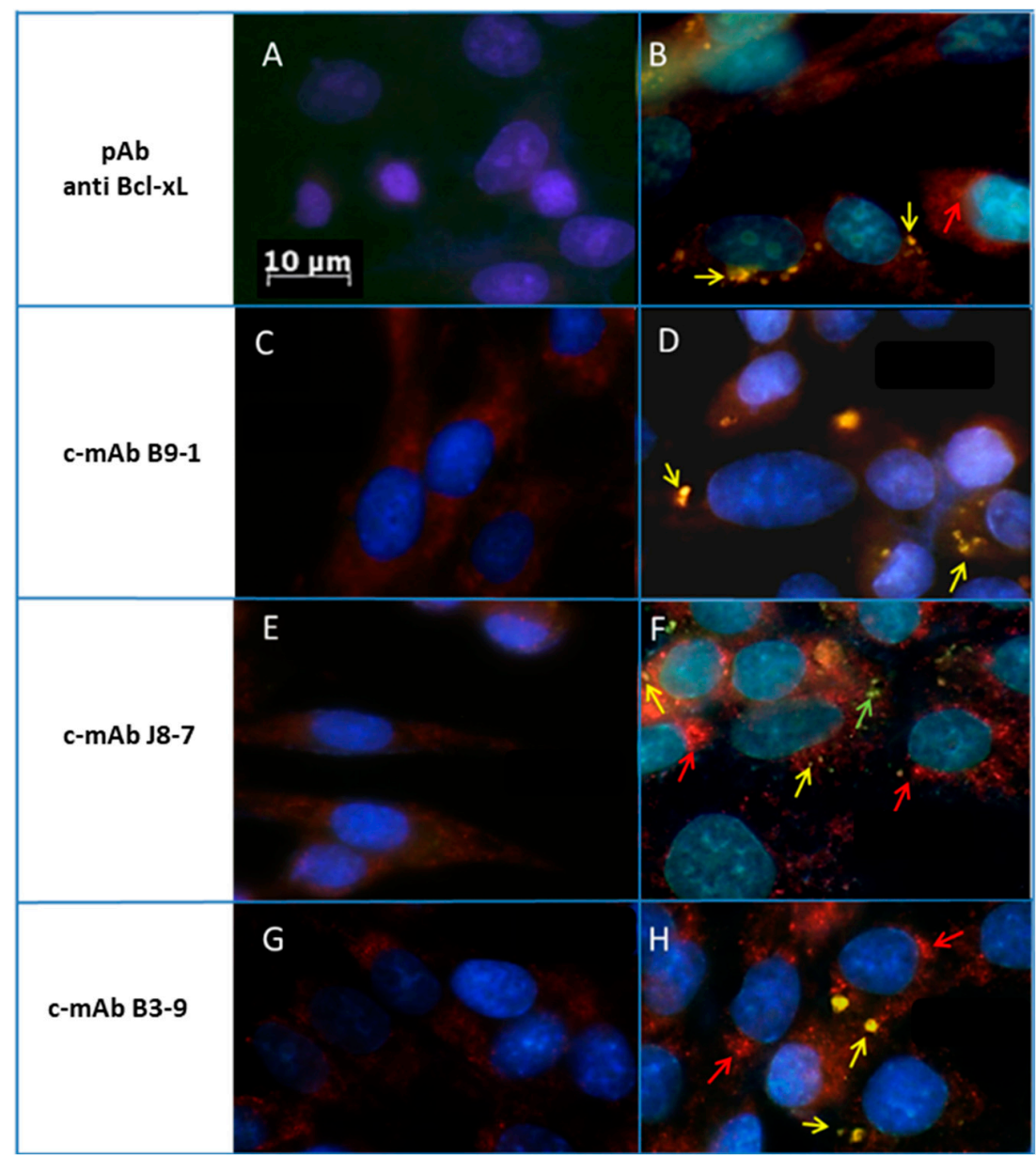

Figure 5. Cellular Bcl-xL detection by immunohistochemistry in SH-SY5Y culture chemically stressed with iron, using commercial polyclonal Bcl-xL antibodies (A-B) and c-mAb (C-H) (visualized at $594 \mathrm{~nm}$, red color) and Thioflavin-T (visualized at $488 \mathrm{~nm}$, green color). Hoechst dye stained the nucleus (visualized at $405 \mathrm{~nm}$, blue color). Pictures resulted from the merging of the three stains. Amyloid Bcl-xL aggregate appeared in yellow as indicated by the arrows. We can note that some aggregates appear in green, suggesting other protein types of amyloid deposits.

\subsection{The B3-9 c-mAb Specifically Immunoprecipitates Bcl-xL from Cells Subjected to Metal-Induced Apoptosis}

The capacity to immunoprecipitate Bcl-xL amyloid fibers was tested with the three c-mAbs, B3-9, J8-7, and B9-1. Only B3-9 pulled down Bcl-xL from iron-stressed cells (Figure 6b). Dot blot assays were stained using a commercial polyclonal anti-Bcl-xL. The recognition of BclxLcf37, BclxLnf70, and Bcl-xL- $\Delta \mathrm{TM}$ monomers by the antibody confirmed its specific recognition of the proteins of interest (Figure 6e-g). The absence of the recognition of proteins in the flow-through fraction confirmed the efficiency of B3-7 when used for IP experiments (Figure $6 c, d$ ). 


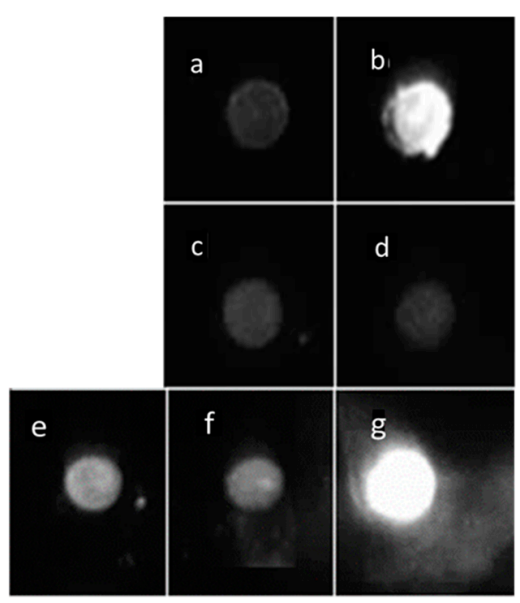

Figure 6. Dot blot of immunoprecipitation (IP) pull-down using B3-9 c-mAb: IP of cell fraction obtained after centrifugation and revealed with the polyclonal anti-Bcl-xL antibody: $(\mathbf{a}, \mathbf{c})$ fraction obtained from SH-SY5Y control and (b,d) SH-SY5Y stressed for $24 \mathrm{~h}$ with $\mathrm{FeCl}_{3} ;(\mathbf{a}, \mathbf{b})$ resulted from IP pull-down; $(\mathbf{c}, \mathbf{d})$ resulted from the flow-through of the IP and constituted the negative control. (e-g) constituted the positive controls with blotting for (e) BclxLcl37, (f) BclxLnf70, and (g) BclxL- $\Delta$ TM monomer.

\section{Discussion}

The cell's pro-survival Bcl-xL, a member of the Bcl-2 family, can form, in vitro, two forms of native-like fibers depending on the temperature of its incubation [51]. Like several other members of the $\mathrm{Bcl}-2$ family, $\mathrm{Bcl}-\mathrm{xL}$ can be cleaved by caspases, enhancing the pro-death activities of these proteins in apoptosis [52]. In this study, firstly in vitro, we show that Bcl-xL, upon caspase like-cleavage, is able to undergo structural modification and aggregation into amyloid fibers. The $\mathrm{N}$-terminal sequencing of Bcl-xL fragments shows that trypsin exhibits a specific proteolytic activity, located within the Arg78Glu79 regulation loop of Bcl-xL, very close to the caspase-3 cleavage site in the loop domain (between Asp76 and Ala77), releasing the BH4-domain associated with an $\alpha$-helix $[17,34,53]$. Bcl-xL cleavage has also been reported to result from different stimuli such as IL-3 withdrawal, virus infection [38], caspase-3-like proteases from an apoptotic CTLL-2 cell lysate [33], or the direct activation of caspase- 9 by chemically induced dimerization [54]. The endogenous cleavage of Bcl-xL by caspases or calpains produces a C-terminal protein $(\Delta \mathrm{N}-\mathrm{Bcl}-\mathrm{xL})$ with a Bax-like pro-apoptotic activity $[38,39]$. To our knowledge, this is the first report that shows in vitro, such cleaved Bcl-xL proteins, $\triangle \mathrm{N}-\mathrm{BCL}-\mathrm{xL}-\Delta \mathrm{TM}$, at a physiological temperature of $37^{\circ} \mathrm{C}$, form fibers with amyloid tinctorial characteristics, as revealed by ThT fluorescence. Further characterization of BclxLcf37 will help to define more of its biophysical features.

To study amyloid BclxLcf37 fibers, and to know whether they exist in vivo and in which cellular context they are found, specific monoclonal antibodies (mAbs) have been produced, by mouse immunization, against the different conformational epitopes of Bcl-xL. Three antibodies (c-mAbs) were selected for their capacity to recognize, specifically, Bcl-xL amyloid fibers [51,55]. Antibody property analysis indicates that all the c-mAbs recognized amyloid or amyloid-like fibers and did not interact with the monomeric states of either native or cleaved $\mathrm{Bcl}-\mathrm{xL}$, in contrast to commercial monoclonal and polyclonal antibodies. We can note that commercial mAbs do not recognize Bclxlcf37, and this may be also due to the loss of its $\mathrm{BH} 4$ domain following the cleavage.

In order to explore its biological role, we examined endogenous Bcl-xL's fate in neural cells under metal-induced oxidative stress, as it is highly expressed in the human brain and could play an important role in neurodegenerative diseases [40].

Transition metals, causing oxidative stress, can induce apoptosis in neural cells as well as neuroinflammation; both are associated with neurodegenerative diseases [56]. In human neuroblastoma (SH-SY5Y), oxidative apoptosis was induced after $24 \mathrm{~h}$ of exposure to metallic stress ( $\mathrm{FeCl} 3, \mathrm{ZnCl}$, 
and $\mathrm{CuCl} 2$ ) which produce ROS. This phenomenon is associated with the activation of the caspase-9, which indicates the activation of the mitochondrial apoptotic pathway together with the involvement of the Bcl-2 family of proteins. After $24 \mathrm{~h}$ of incubation, according to fluorescence microscopy, Bcl-xL was immuno-localized in intracellular aggregates with amyloid features, as revealed by ThT staining. Overall, these results indicate that the disruption of metal homeostasis provokes cell apoptosis and leads to conformational changes in Bcl-xL.

Metal imbalance, even at low concentrations, could readily foster the oligomerization and aggregation of several proteins implicated in neurodegenerative diseases [3]. Thereby, $\mathrm{A} \beta$ oligomerizes with $\mathrm{Cu}$ and $\mathrm{Zn}$ [57], tau protein oligomerizes in presence of the trivalent metal ions $\mathrm{Al}$ (III) and $\mathrm{Fe}(\mathrm{III})$ [58], and $\alpha$ Syn can also oligomerize in the presence of different metals including $\mathrm{Al}(\mathrm{III})$, $\mathrm{Cu}(\mathrm{II}), \mathrm{Cd}(\mathrm{II})$, and $\mathrm{Fe}(\mathrm{III})$ [59]. This enhancement, readily favored by the presence of binding sites for neurometals within proteins, leads to metal sequestration into amyloid plaques. The presence of binding sites inside the protein's structure fosters the aggregation and toxic reactions through an increase in the reactive oxygen species (ROS) concentration through Fenton and Haber-Weiss reactions [60]. The direct consequence of these metal bonds with proteins is a high concentration of sequestered metals in amyloid deposits, which could locally participate in the oxidative stress at the origin of neural apoptosis and of neuronal and synaptic disruption due to the production of ROS. The potential presence of metal binding sites in Bcl-xL remains to be unveiled to understand the pathophysiological significance of amyloid aggregates of Bcl-xL during apoptosis induced by oxidative stress from metals. The new c-mAbs will be useful for deciphering this process and especially since it is described that $\mathrm{Bcl}-\mathrm{xL}$ is cleaved by caspase-3 inside exosomes in order to participate in cell-to-tumor cell communication [61].

Taken together, these results are of high interest for the in vivo characterization of Bcl-xL behavior in the context of cells undergoing metallic stresses. We chose to overexpose neuroblastoma cells to metals essential for life, i.e., $\mathrm{Fe}, \mathrm{Cu}$, and $\mathrm{Zn}$, which are found in high concentrations in the brains of patients with neurodegenerative diseases. We confirmed that metal-induced apoptosis is associated with ROS production and caspase-9 activation and leads to endogenous Bcl-xL accumulation in intracellular and amyloidogenic aggregates. Using the c-mAb specific for $\mathrm{Bcl}-\mathrm{xL}$ fibers, we have shown that $\mathrm{Bcl}-\mathrm{xL}$ is included in aggregates of amyloid structures after apoptosis induction. Moreover, one of these c-mAbs can be used to isolate Bcl-xL fibers for further structural analyses. These c-mAbs strongly recognize Bcl-xL aggregated in amyloid fibers: the c-mAbs co-localizes only with the amyloid dye Thioflavin $\mathrm{T}$ in cells under apoptotic stress.

In conclusion, we show that the Bcl-xL protein can undergo dramatic conformational changes both in cellulo and in vitro under oxidative conditions, leading to the accumulation of $\mathrm{Bcl}-\mathrm{xL}$ in aggregates of amyloid features. The self-propagating behavior of Bcl-xL appears to be strongly dependent on its biophysical state, as described for the canonical amyloid aggregation of the amyloid protein, i.e., $A \beta$ or $\alpha$ Syn [62]. This is supported by the fact that fibrils constituted by the cleaved form of Bcl-xL present the characteristics of canonical amyloidal structures, whereas the fibrils from the native Bcl-xL exhibit native-like conformations [51]. This strongly suggests that Bcl-xL conformational changes result from caspase activation in apoptotic cells. The conformational antibodies characterized in this study will allow the identification of the structure of Bcl-xL in these aggregates and their protein composition, which might be crucial for understanding their role in the context of neurodegenerative disease initiation and propagation. Finally, these conformational mAbs could also be considered as useful tools for the early diagnosis and the follow-up of brain lesions, using imaging detection in the context of abnormal rates of apoptosis in a neurodegenerative environment. 


\section{Materials and Methods}

\subsection{Generation of Fibrils}

The recombinant native Bcl-xL- $\Delta$ TM protein used in these experiments was obtained by purification from bacterial production as previously described [51]. Two kinds of Bcl-xL- $\Delta \mathrm{TM}$ fibrils were generated with the entire native protein, denominated "BclxLnf37" and "BclxLnf70", depending on the temperature of incubation as previously established in the laboratory [51]. Briefly, BclxLnf37 was formed using a $200 \mu \mathrm{M}$ concentration of recombinant native Bcl-xL- $\Delta \mathrm{TM}$ monomer incubated at $37^{\circ} \mathrm{C}$, and BclxLnf70 was obtained with a $100 \mu \mathrm{M}$ concentration of recombinant native Bcl-xL- $\Delta \mathrm{TM}$ monomer at $70{ }^{\circ} \mathrm{C}$; both were generated in phosphate buffer $(20 \mathrm{mM}$ phosphate buffer, $50 \mathrm{mM} \mathrm{NaCl}, \mathrm{pH}$, $200 \mu \mathrm{M}$ AEBSF protease inhibitor (Sigma-Aldrich \#A8456)). A new, third type of Bcl-xL fibril, called "BclxLcf37", was obtained after the cleavage of recombinant native Bcl-xL- $\Delta$ TM monomer $(200 \mu M)$ by enzymatic treatment using trypsin (200 nM, TPCK-treated, Sigma-Aldrich \#4352157) at $37^{\circ} \mathrm{C}$ for $30 \mathrm{~min}$; the reaction was stopped by the addition of $200 \mu \mathrm{M}$ AEBSF protease inhibitor. This cleaved protein, $\Delta \mathrm{N}$-Bcl-xL- $\Delta \mathrm{TM}$, was incubated at $37^{\circ} \mathrm{C}$ in phosphate buffer $(20 \mathrm{mM}$ phosphate buffer, $50 \mathrm{mM}$ $\mathrm{NaCl}, \mathrm{pH} 7)$ to generate BclxLcf37 fibrils.

\subsection{Electron Microscopy}

The negative stain Mica-carbon flotation technique (MFT) was used. Samples were adsorbed on the clean side of a carbon film on mica, stained, and transferred to a 400-mesh copper grid. Images were taken under low dose conditions $\left(<10 \mathrm{e}^{-} / \AA^{2}\right)$ with defocus values between 1.2 and $2.5 \mu \mathrm{m}$ on a Tecnai 12 LaB6 electron microscope at a $120 \mathrm{kV}$ accelerating voltage using a CCD Camera, Gatan Orius 1000 .

\subsection{Fluorescence Spectroscopy Experiments}

Bcl-xL amyloid fibrils were analyzed using a Fluorolog FL3-22 spectrophotometer from Horiba-Jobin Yvon Spex. Fluorescence measurement studies of cleaved or entire Bcl-xL fibrils were carried out using $20 \mu \mathrm{M}$ protein in the presence of $20 \mu \mathrm{M}$ thioflavin T analyzed in a Quartz Suprazil cell, at the steady state of the binding of ThT, for fluorescence using a Jasco FP-750 spectrometer (fluorescence: Ex.: 440 nm, Em.: 450-550 nm).

\subsection{Production and Purification of Specific Conformational Monoclonal Antibodies (mAbs) Against Amyloid Bcl-xL Fibers}

Biozzi mice were immunized subcutaneously with $10 \mathrm{mg}$ of native Bcl-xL- $\Delta \mathrm{TM}$ monomer, BclxLnf70, BclxLnf37, or BclxLcf37 with complete Freund's adjuvant. Subsequently, 4 to 6 booster injections of $10 \mathrm{mg}$ of the different conformations of Bcl-xL with incomplete Freund's adjuvant were given subcutaneously at 1-day intervals. After the last injection, the mice were bled and the polyclonal response was tested by ELISA. The mouse that showed the best response against the immunogen was sacrificed for splenic cell fusion according to Kohler and Milstein [63]. Supernatants were screened by ELISA for antibody production (supplementary results, supplementary Table S1). The specificity of the positive supernatants was then tested with different forms of Bcl-xL. Selected hybridoma cells were then cloned by the limiting dilution technique, tested by ELISA. Positive clones were cultivated for ascites production. Four fusions with mice injected with different forms of Bcl-xL were performed. Monoclonal antibodies were purified from ascites by precipitation with ammonium sulfate, centrifuged, and dialyzed against PBS. Through this process, three mAbs were selected for their efficiency in targeting Bcl-xL-positive fibers/oligomers and, at the same time, not recognizing Bcl-xL- $\Delta \mathrm{TM}$ monomer. These mAbs were produced from hybridomas called B9-1, B7-3, and J8-7. In the rest of the article, these names will be used as the $\mathrm{mAb}$ names. The cell lines producing the antibodies described in this article are available on request from the Collection Nationale de Cultures de Microorganismes 
(CNCM) at Institut Pasteur, Paris: https://www.pasteur.fr/fr/recherche-cncm. This study was approved by Minister of French Research and Institut Pasteur ethics committee (project $n^{\circ} 00802.02,20 / 11 / 2015$ ).

\subsection{Dot Blotting}

Conformational antibody characterization was performed by dot blotting using BclxLnf37, BclxLnf70, BclxLcf37, Bcl-xL- $\Delta$ TM monomer, $\mathrm{A} \beta$ fibers and $\mathrm{A} \beta$ monomer as a target on nitrocellulose membranes (Hybond-ECL-Amersham Biosciences). Following a short centrifugation, $10 \mu \mathrm{g}$ of BclxLnf70, BclxLnf37, BclxLcf37, or A $\beta$ fibrils and of Bcl-xL- $\Delta \mathrm{TM}$ monomer were spotted on the membrane and dried for $30 \mathrm{~min}$. After blockage at room temperature with PBS-Tween 20/10\% milk and washing in PBS-Tween 20/5\% milk, the membranes were incubated with either a rabbit polyclonal anti-Bcl-xL Ab (BD Bioscience; 1/2000) or mouse monoclonal anti-Bcl-xL Ab (3-14) (obtained against the N-terminal part (3-14) of Bcl-xL; BD Bioscience; 1/2000) or with the mAbs to be characterized (1/5000) in PBS-Tween 20/5\% milk. After three washes, they were incubated with a secondary goat anti-rabbit or rabbit anti-mouse Ab coupled to HRP (horseradish peroxidase) (BETHYL laboratories; 1/5000) in PBS-Tween 20/5\% milk. Binding was revealed with a mixture of the SuperSignal ${ }^{\mathrm{TM}}$ West Pico PLUS Chemiluminescent Substrate (ThermoScientific \#34579). Signals were observed using the Molecular Imager device (Fusion FX7, ThermoFischer).

\subsection{Cell Culture}

Human SH-SY5Y neuroblastoma cells (ATCC \#CRL 2266) were grown in Dulbecco's modified Eagle's medium F-12 (DMEM: F-12) supplemented with 1\% penicillin-streptomycin and 10\% fetal calf serum (Invitrogen). Adherent cells were grown in DMEM/F12 1:1 (Dulbecco's modified Eagle's medium) supplemented with $2 \mathrm{mM}$ L-glutamine and $1.2 \mathrm{~g} / \mathrm{L}$ sodium bicarbonate, $1 \%$ penicillin-streptomycin (Invitrogen), and $10 \%$ heat-inactivated fetal calf serum (Invitrogen), at $37^{\circ} \mathrm{C}$, under $5 \% \mathrm{CO}_{2}$.

\subsection{Metal Oxidative Stress}

Iron ( $\mathrm{FeCl}_{3}$, Sigma, France), copper $\left(\mathrm{CuCl}_{2}\right.$, Acros Organics, France), and zinc $\left(\mathrm{ZnCl}_{2}, \mathrm{Acros}\right.$ Organics, France) were used to induce oxidative stress in SH-SY5Y cells. Metal solutions were added to the culture medium at the following concentrations: $\left[\mathrm{FeCl}_{3}\right]=300 \mu \mathrm{M},\left[\mathrm{CuCl}_{2}\right]=500 \mu \mathrm{M}$, and $\left[\mathrm{ZnCl}_{2}\right]=150 \mu \mathrm{M}$. These metal concentrations correspond to the effective concentrations causing the cell death of $50 \%$ of the cell population after $24 \mathrm{~h}$ of incubation (Supplementary Figure S1). Hydrogen peroxide at $100 \mu \mathrm{M}\left(\mathrm{H}_{2} \mathrm{O}_{2}\right.$, Sigma \#216763) was used as a positive control for oxidative stress and apoptosis. Unstressed cells were used as negative controls. The metal solutions were applied for $24 \mathrm{~h}$, whereas the stress by hydrogen peroxide was applied for $30 \mathrm{~min}$, and then, the medium was replaced with fresh medium and the cells were incubated for $24 \mathrm{~h}$.

\subsection{Flow Cytometry}

Apoptosis was evaluated using an Annexin V-PE Apoptosis Detection Kit (BD Pharmingen). Cells were recovered after $24 \mathrm{~h}$ of stress and were suspended in $1 \mathrm{X}$ binding buffer solution to obtain $10^{6}$ cells $/ \mathrm{mL}$. We collected $100 \mu \mathrm{L}$ of cells and stained them with $5 \mu \mathrm{L}$ of annexin V labeled with phycoerythrin (PE) and $5 \mu \mathrm{L}$ of 7-amino-actinomycin (7AAD). After 15 min of incubation, we performed the measurement of the signal emitted by labeled cells on a FACS Calibur flow cytometer (Becton Dickinson, Franklin Lakes, NJ, USA). The specific signal was adjusted according to controls consisting of 1) unstressed cells and unlabeled cells, 2) cells stained only with annexin V-PE, and 3) cells stained only with 7AAD.

\subsection{Immunofluorescence}

Cells were seeded and cultivated on poly-ornithine-coated glass $24 \mathrm{~h}$ before the application of metal stress. Following metal treatments, cells were fixed with $5 \%$ formalin for $20 \mathrm{~min}$ at room 
temperature, after 3 washes of $5 \mathrm{~min}$, and then permeabilized with $80 \%$ methanol at $-20{ }^{\circ} \mathrm{C}$ for $6 \mathrm{~min}$, followed by $1 \mathrm{~h} 30 \mathrm{~min}$ of saturation with PBS-NP-40 at $0.05 \%$. The immunostaining was performed with primary antibodies in PBS-NP40 0.05\%: mouse monoclonal and rabbit polyclonal anti-Bcl-xL antibodies (BD Biosciences; 1/1000), and rabbit anti-caspase-9 antibody (USBiological; 1/1000). The primary antibodies were incubated overnight at $4{ }^{\circ} \mathrm{C}$, and following 3 washes, the secondary rabbit anti-mouse antibodies coupled with Alexa- 546 or goat anti-rabbit antibodies coupled with Alexa-647 or Alexa-594 (Invitrogen; 1/1000) were incubated for $1 \mathrm{~h}$, at room temperature, in PBS-NP-40 at $0.05 \%$. Then, Thioflavin T (Sigma-Aldrich, \#T3516) at $0.05 \%$ in $\mathrm{H}_{2} \mathrm{O}$ was used to specifically stain amyloid aggregates $\left(5 \mathrm{~min}\right.$ at $4{ }^{\circ} \mathrm{C}$ in the dark). The coated pieces of glass were mounted on slides with mounting medium containing Hoechst dye, DABCO (1,4-diazabicyclo [2,2,2] octane, Sigma), and Mowiol. The slices were observed for Alexa-546 $(\lambda \mathrm{exc}=543 \mathrm{~nm} ; \lambda \mathrm{em}=590 \mathrm{~nm})$, Alexa-647 $(\lambda$ exc $=637 \mathrm{~nm} ; \lambda \mathrm{em}=650 \mathrm{~nm})$, Hoechst $(\lambda \mathrm{exc}=330 \mathrm{~nm} ; \lambda \mathrm{em}=450 \mathrm{~nm})$, and Thioflavin $\mathrm{T}$ $(\lambda \mathrm{exc}=488 \mathrm{~nm} ; \lambda \mathrm{em}=515 \mathrm{~nm})$ staining using a confocal microscope (Leica TCS-SP2).

\subsection{Immuno-Precipitation (IP) Experiments}

Oxidative stress was applied to confluent cells $24 \mathrm{~h}$ before lysis. The supernatants were removed from the cells, which were put on ice with $2 \mathrm{~mL}$ of RIPA lysis buffer $(\mathrm{NaCl} 150 \mathrm{mM}, 1 \% \mathrm{NP}-40$ lysis buffer; $0.4 \%$ deoxycholate; Tris, 50 mM; pH 7.4) + 1X Halt Protease Inhibitor Cocktail (\#RH238656, ThermoFisher) for $30 \mathrm{~min}$. Lysed cells were suspended mechanically using scrappers and added back to their respective supernatants. A first centrifugation with a Centrifuge $5810 \mathrm{R}$ (Eppendorf) at $1000 \times \mathrm{g}$ for $10 \mathrm{~min}$ helped to remove nuclei and whole cells; the pellet was discarded. A second at $10,000 \times g$ for 20 min helped to remove microsomes, small vesicles, ribosomes, macromolecules, and soluble proteins. An ultracentrifugation at $80,000 \times g$ for $1 \mathrm{~h}$ with an Optima XPN Ultracentrifuge (Beckman Coulter) enabled the retrieving of non-soluble proteins in the pellet, which were used for further experiments. Immunoprecipitation was performed using Protein $\mathrm{G}$ coated with sepharose (Protein G Sepharose ${ }^{\mathrm{TM}} 4$ Fast Flow \#17-6002-35, GE Healthcare) washed with lysis buffer. Pre-clearing for $1 \mathrm{~h}$ with a $50 \%$ bead suspension was systematically carried out before adding antibodies at their recommended concentrations. The incubation with antibodies was performed for at least $2 \mathrm{~h}$ at $4{ }^{\circ} \mathrm{C}$ under rotation, and $100 \mu \mathrm{L}$ of Protein G beads were then added per $500 \mu \mathrm{L}$ of aliquots to allow the formation of immune complexes. The flow-through was retrieved, and complexes were dissociated owing to successive suspensions in lysis buffer, basic buffer $\left(\mathrm{NaH}_{2} \mathrm{PO}_{4} 0.2 \mathrm{M}, \mathrm{NaCl} 0.13 \mathrm{M}, \mathrm{pH} 8\right)$ and acidic buffer $\left(\mathrm{Na}_{2} \mathrm{HPO}_{4} 0.2 \mathrm{M}\right.$, citric acid $\left.0.1 \mathrm{M}, \mathrm{pH} 3\right)$, with a centrifugation between each step to remove the supernatant. Binding was revealed by dot blotting with a commercial polyclonal anti-Bcl-xL $(\mathrm{pAb})$ (Invitrogen) on the nitrocellulose membranes where the samples were deposited.

Supplementary Materials: Supplementary materials can be found at http://www.mdpi.com/1422-0067/21/20/ 7625/s1.

Author Contributions: Conceptualization, C.A., A.C., V.F. and C.M.; Data curation, C.M.; Formal analysis, A.G., F.-Z.F., A.C., V.F. and C.M.; Funding acquisition, V.F.; Investigation, A.G., F.-Z.F., E.L., E.L.T. and C.M.; Methodology, E.C.-G., A.C. and C.M.; Project administration, C.M.; Supervision, C.M.; Visualization, F.-Z.F. and C.M.; Writing-original draft, V.F. and C.M.; Writing-review \& editing, A.G., F.Z.F., E.C.-G., C.A., A.C., V.F. and C.M. All authors have read and agreed to the published version of the manuscript.

Funding: This work was supported by ANR-IDEX-NeuroCoG 2019-2020.

Acknowledgments: We thank Fenel Daphna and Schoehn Guy, from the IBS/UVHCI platform of the Partnership for Structural Biology in Grenoble (PSB/IBS), for the electron microscopy. The authors thank Sylvie Dartevelle and Farida Nato, from the Pasteur Institute, for technical experiments regarding hybridoma selection.

Conflicts of Interest: The authors declare no conflict of interest. 


\section{References}

1. Tamano, H.; Takeda, A. Dynamic action of neurometals at the synapse. Metallomics 2011, 3, 656-661. [CrossRef] [PubMed]

2. Cicero, C.E.; Mostile, G.; Vasta, R.; Rapisarda, V.; Signorelli, S.S.; Ferrante, M.; Zappia, M.; Nicoletti, A. Metals and neurodegenerative diseases. A systematic review. Environ. Res. 2017, 159, 82-94. [CrossRef] [PubMed]

3. Kawahara, M.; Kato-Negishi, M.; Tanaka, K. Cross talk between neurometals and amyloidogenic proteins at the synapse and the pathogenesis of neurodegenerative diseases. Metallomics 2017, 9, 619-633. [CrossRef] [PubMed]

4. $\quad$ Reybier, K.; Ayala, S.; Alies, B.; Rodrigues, J.V.; Bustos Rodriguez, S.; La Penna, G.; Collin, F.; Gomes, C.M.; Hureau, C.; Faller, P. Free Superoxide is an Intermediate in the Production of $\mathrm{H}_{2} \mathrm{O}_{2}$ by Copper(I)-A $\beta$ Peptide and $\mathrm{O}_{2}$. Angew. Chem. Int. Ed. 2016, 55, 1085-1089. [CrossRef] [PubMed]

5. Telling, N.D.; Everett, J.; Collingwood, J.F.; Dobson, J.; van der Laan, G.; Gallagher, J.J.; Wang, J.; Hitchcock, A.P. Iron Biochemistry is Correlated with Amyloid Plaque Morphology in an Established Mouse Model of Alzheimer's Disease. Cell Chem. Biol. 2017, 24, 1205-1215.e3. [CrossRef] [PubMed]

6. Ganguly, G.; Chakrabarti, S.; Chatterjee, U.; Saso, L. Proteinopathy, oxidative stress and mitochondrial dysfunction: Cross talk in Alzheimer's disease and Parkinson's disease. Drug Des. Devel. Ther. 2017, 11, 797-810. [CrossRef]

7. Leuner, K.; Müller, W.E.; Reichert, A.S. From mitochondrial dysfunction to amyloid beta formation: Novel insights into the pathogenesis of Alzheimer's disease. Mol. Neurobiol. 2012, 46, 186-193. [CrossRef]

8. Paola, D.; Domenicotti, C.; Nitti, M.; Vitali, A.; Borghi, R.; Cottalasso, D.; Zaccheo, D.; Odetti, P.; Strocchi, P.; Marinari, U.M.; et al. Oxidative stress induces increase in intracellular amyloid beta-protein production and selective activation of betaI and betaII PKCs in NT2 cells. Biochem. Biophys. Res. Commun. 2000, 268, 642-646. [CrossRef]

9. Tamagno, E.; Bardini, P.; Obbili, A.; Vitali, A.; Borghi, R.; Zaccheo, D.; Pronzato, M.A.; Danni, O.; Smith, M.A.; Perry, G.; et al. Oxidative stress increases expression and activity of BACE in NT2 neurons. Neurobiol. Dis. 2002, 10, 279-288. [CrossRef]

10. Fischer, R.; Maier, O. Interrelation of oxidative stress and inflammation in neurodegenerative disease: Role of TNF. Oxid. Med. Cell. Longev. 2015, 2015, 610813. [CrossRef]

11. Islam, M.T. Oxidative stress and mitochondrial dysfunction-linked neurodegenerative disorders. Neurol. Res. 2017, 39, 73-82. [CrossRef] [PubMed]

12. Anilkumar, U.; Prehn, J.H.M. Anti-apoptotic BCL-2 family proteins in acute neural injury. Front. Cell. Neurosci. 2014, 8. [CrossRef] [PubMed]

13. Czabotar, P.E.; Lessene, G.; Strasser, A.; Adams, J.M. Control of apoptosis by the BCL-2 protein family: Implications for physiology and therapy. Nat. Rev. Mol. Cell Biol. 2014, 15, 49-63. [CrossRef]

14. Wei, M.C.; Zong, W.-X.; Cheng, E.H.-Y.; Lindsten, T.; Panoutsakopoulou, V.; Ross, A.J.; Roth, K.A.; MacGregor, G.R.; Thompson, C.B.; Korsmeyer, S.J. Proapoptotic BAX and BAK: A Requisite Gateway to Mitochondrial Dysfunction and Death. Science 2001, 292, 727-730. [CrossRef]

15. Hsu, Y.-T.; Wolter, K.G.; Youle, R.J. Cytosol-to-membrane redistribution of Bax and Bcl-XL during apoptosis. Proc. Natl. Acad. Sci. USA 1997, 94, 3668-3672. [CrossRef]

16. Happo, L.; Strasser, A.; Cory, S. BH3-only proteins in apoptosis at a glance. J. Cell Sci. 2012, 125, $1081-1087$. [CrossRef] [PubMed]

17. Cheng, E.H. Conversion of Bcl-2 to a Bax-like Death Effector by Caspases. Science 1997, 278, $1966-1968$. [CrossRef]

18. Sattler, M.; Liang, H.; Nettesheim, D.; Meadows, R.P.; Harlan, J.E.; Eberstadt, M.; Yoon, H.S.; Shuker, S.B.; Chang, B.S.; Minn, A.J.; et al. Structure of Bcl-xL-Bak Peptide Complex: Recognition Between Regulators of Apoptosis. Science 1997, 275, 983-986. [CrossRef]

19. Ivanovska, I.; Galonek, H.L.; Hildeman, D.A.; Hardwick, J.M. Regulation of cell death in the lymphoid system by Bcl-2 family proteins. Acta Haematol. 2004, 111, 42-55. [CrossRef]

20. Soane, L.; Siegel, Z.T.; Schuh, R.A.; Fiskum, G. Postnatal Developmental Regulation of Bcl-2 Family Proteins in Brain Mitochondria. J. Neurosci. Res. 2008, 86, 1267-1276. [CrossRef] 
21. Beaumatin, F.; El Dhaybi, M.; Bobo, C.; Verdier, M.; Priault, M. Bcl-xL deamidation and cancer: Charting the fame trajectories of legitimate child and hidden siblings. Biochim. Biophys. Acta BBA-Mol. Cell Res. 2017, 1864, 1734-1745. [CrossRef] [PubMed]

22. Seng, N.; Megyesi, J.; Tarcsafalvi, A.; Price, P. Mimicking Cdk2 phosphorylation of Bcl-xL at Ser73 results in caspase activation and Bcl-xL cleavage. Cell Death Discov. 2016, 2, 16001. [CrossRef]

23. Kharbanda, S.; Pandey, P.; Schofield, L.; Israels, S.; Roncinske, R.; Yoshida, K.; Bharti, A.; Yuan, Z.-M.; Saxena, S.; Weichselbaum, R.; et al. Role for Bcl-xL as an inhibitor of cytosolic cytochrome C accumulation in DNA damage-induced apoptosis. Proc. Natl. Acad. Sci. USA 1997, 94, 6939-6942. [CrossRef] [PubMed]

24. Kim, C.N.; Wang, X.; Huang, Y.; Ibrado, A.M.; Liu, L.; Fang, G.; Bhalla, K. Overexpression of Bcl-X(L) inhibits Ara-C-induced mitochondrial loss of cytochrome $\mathrm{c}$ and other perturbations that activate the molecular cascade of apoptosis. Cancer Res. 1997, 57, 3115-3120. [PubMed]

25. Carthy, C.M.; Yanagawa, B.; Luo, H.; Granville, D.J.; Yang, D.; Cheung, P.; Cheung, C.; Esfandiarei, M.; Rudin, C.M.; Thompson, C.B.; et al. Bcl-2 and Bcl-xL overexpression inhibits cytochrome c release, activation of multiple caspases, and virus release following coxsackievirus B3 infection. Virology 2003, 313, 147-157. [CrossRef]

26. Zaidi, A.U.; D’Sa-Eipper, C.; Brenner, J.; Kuida, K.; Zheng, T.S.; Flavell, R.A.; Rakic, P.; Roth, K.A. Bcl-X (L) -Caspase-9 Interactions in the Developing Nervous System: Evidence for Multiple Death Pathways. J. Neurosci. 2001, 21, 169-175. [CrossRef] [PubMed]

27. Bruey, J.-M.; Bruey-Sedano, N.; Luciano, F.; Zhai, D.; Balpai, R.; Xu, C.; Kress, C.L.; Bailly-Maitre, B.; Li, X.; Osterman, A.; et al. Bcl-2 and Bcl-XL Regulate Proinflammatory Caspase-1 Activation by Interaction with NALP1. Cell 2007, 129, 45-56. [CrossRef] [PubMed]

28. Chen, Y.; Aon, M.A.; Hsu, Y.-T.; Soane, L.; Teng, X.; McCaffery, J.M.; Cheng, W.-C.; Qi, B.; Li, H.; Alavian, K.N.; et al. Bcl-xL regulates mitochondrial energetics by stabilizing the inner membrane potential. J. Cell Biol. 2011, 195, 263-276. [CrossRef]

29. Alavian, K.N.; Li, H.; Collis, L.; Bonanni, L.; Zeng, L.; Sacchetti, S.; Lazrove, E.; Nabili, P.; Flaherty, B.; Graham, M.; et al. Bcl-xL regulates metabolic efficiency of neurons through interaction with the mitochondrial F1FO ATP synthase. Nat. Cell Biol. 2011, 13, 1224-1233. [CrossRef]

30. Li, H.; Chen, Y.; Jones, A.F.; Sanger, R.H.; Collis, L.P.; Flannery, R.; McNay, E.C.; Yu, T.; Schwarzenbacher, R.; Bossy, B.; et al. Bcl-xL induces Drp1-dependent synapse formation in cultured hippocampal neurons. Proc. Natl. Acad. Sci. USA 2008, 105, 2169-2174. [CrossRef]

31. Park, H.-A.; Licznerski, P.; Alavian, K.N.; Shanabrough, M.; Jonas, E.A. Bcl-xL Is Necessary for Neurite Outgrowth in Hippocampal Neurons. Antioxid. Redox Signal. 2015, 22, 93-108. [CrossRef] [PubMed]

32. Hyman, B.T.; Yuan, J. Apoptotic and non-apoptotic roles of caspases in neuronal physiology and pathophysiology. Nat. Rev. Neurosci. 2012, 13, 395-406. [CrossRef] [PubMed]

33. Fujita, N.; Nagahashi, A.; Nagashima, K.; Rokudai, S.; Tsuruo, T. Acceleration of apoptotic cell death after the cleavage of Bcl-XL protein by caspase-3-like proteases. Oncogene 1998, 17, 1295-1304. [CrossRef] [PubMed]

34. Condorelli, F.; Salomoni, P.; Cotteret, S.; Cesi, V.; Srinivasula, S.M.; Alnemri, E.S.; Calabretta, B. Caspase cleavage enhances the apoptosis-inducing effects of BAD. Mol. Cell. Biol. 2001, 21, 3025-3036. [CrossRef]

35. Li, P.; Nijhawan, D.; Budihardjo, I.; Srinivasula, S.M.; Ahmad, M.; Alnemri, E.S.; Wang, X. Cytochrome c and dATP-dependent formation of Apaf-1/caspase-9 complex initiates an apoptotic protease cascade. Cell 1997, 91, 479-489. [CrossRef]

36. Nakagawa, T.; Yuan, J. Cross-talk between two cysteine protease families. Activation of caspase-12 by calpain in apoptosis. J. Cell Biol. 2000, 150, 887-894. [CrossRef]

37. Wood, D.E.; Newcomb, E.W. Cleavage of Bax enhances its cell death function. Exp. Cell Res. 2000, 256, 375-382. [CrossRef]

38. Clem, R.J.; Cheng, E.H.-Y.; Karp, C.L.; Kirsch, D.G.; Ueno, K.; Takahashi, A.; Kastan, M.B.; Griffin, D.E.; Earnshaw, W.C.; Veliuona, M.A.; et al. Modulation of cell death by Bcl-xL through caspase interaction. Proc. Natl. Acad. Sci. USA 1998, 95, 554-559. [CrossRef]

39. Jonas, E.A.; Hickman, J.A.; Chachar, M.; Polster, B.M.; Brandt, T.A.; Fannjiang, Y.; Ivanovska, I.; Basañez, G.; Kinnally, K.W.; Zimmerberg, J.; et al. Proapoptotic N-truncated BCL-xL protein activates endogenous mitochondrial channels in living synaptic terminals. Proc. Natl. Acad. Sci. USA 2004, 101, 13590-13595. [CrossRef] 
40. Krajewska, M.; Mai, J.; Zapata, J.; Ashwell, K.; Schendel, S.; Reed, J.; Krajewski, S. Dynamics of expression of apoptosis-regulatory proteins Bid, Bcl-2, Bcl-X, Bax and Bak during development of murine nervous system. Cell Death Differ. 2002, 9, 145-157. [CrossRef]

41. Hickman, J.A.; Hardwick, J.M.; Kaczmarek, L.K.; Jonas, E.A. Bcl-xL Inhibitor ABT-737 Reveals a Dual Role for Bcl-xL in Synaptic Transmission. J. Neurophysiol. 2008, 99, 1515-1522. [CrossRef] [PubMed]

42. Jonas, E.A.; Hickman, J.A.; Hardwick, J.M.; Kaczmarek, L.K. Exposure to Hypoxia Rapidly Induces Mitochondrial Channel Activity within a Living Synapse. J. Biol. Chem. 2005, 280, 4491-4497. [CrossRef]

43. Ofengeim, D.; Chen, Y.; Miyawaki, T.; Li, H.; Sacchetti, S.; Flannery, R.J.; Alavian, K.N.; Pontarelli, F.; Roelofs, B.A.; Hickman, J.A.; et al. N-terminally cleaved Bcl-xL mediates ischemia-induced neuronal death. Nat. Neurosci. 2012, 15, 574-580. [CrossRef] [PubMed]

44. Park, H.-A.; Licznerski, P.; Mnatsakanyan, N.; Niu, Y.; Sacchetti, S.; Wu, J.; Polster, B.M.; Alavian, K.N.; Jonas, E.A. Inhibition of Bcl-xL prevents pro-death actions of $\triangle \mathrm{N}-\mathrm{Bcl}-\mathrm{xL}$ at the mitochondrial inner membrane during glutamate excitotoxicity. Cell Death Differ. 2017, 24, 1963-1974. [CrossRef]

45. Ruvolo, P.P.; Deng, X.; May, W.S. Phosphorylation of Bcl2 and regulation of apoptosis. Leukemia 2001, 15, 515-522. [CrossRef] [PubMed]

46. Li, D.; Ueta, E.; Kimura, T.; Yamamoto, T.; Osaki, T. Reactive oxygen species (ROS) control the expression of Bcl-2 family proteins by regulating their phosphorylation and ubiquitination. Cancer Sci. 2004, 95, 644-650. [CrossRef]

47. Boise, L.H.; Gonzalez-Garcia, M.; Postema, C.E.; Ding, L.; Lindsten, T.; Turka, L.A.; Mao, X.; Nunez, G.; Thompson, C.B. bcl-x, a bcl-2-related gene that functions as a dominant regulator of apoptotic cell death. Cell 1993, 74, 597-608. [CrossRef]

48. Urrutia, P.J.; Mena, N.P.; Nunez, M.T. The interplay between iron accumulation, mitochondrial dysfunction, and inflammation during the execution step of neurodegenerative disorders. Front. Pharmacol. 2014, 5. [CrossRef]

49. Megyesi, J.; Tarcsafalvi, A.; Seng, N.; Hodeify, R.; Price, P.M. Cdk2 phosphorylation of Bcl-xL after stress converts it to a pro-apoptotic protein mimicking Bax/Bak. Cell Death Discov. 2016, 2, 15066. [CrossRef]

50. Brutus, N.A.; Hanley, S.; Ashraf, Q.M.; Mishra, O.P.; Delivoria-Papadopoulos, M. Effect of Hyperoxia on Serine Phosphorylation of Apoptotic Proteins in Mitochondrial Membranes of the Cerebral Cortex of Newborn Piglets. Neurochem. Res. 2009, 34, 1219-1225. [CrossRef]

51. Chenal, A.; Vendrely, C.; Vitrac, H.; Karst, J.C.; Gonneaud, A.; Blanchet, C.E.; Pichard, S.; Garcia, E.; Salin, B.; Catty, P.; et al. Amyloid Fibrils Formed by the Programmed Cell Death Regulator Bcl-xL. J. Mol. Biol. 2012, 415, 584-599. [CrossRef] [PubMed]

52. Kutuk, O.; Basaga, H. Bcl-2 protein family: Implications in vascular apoptosis and atherosclerosis. Apoptosis 2006, 11, 1661-1675. [CrossRef] [PubMed]

53. Li, M.; Wang, D.; He, J.; Chen, L.; Li, H. Bcl-XL: A multifunctional anti-apoptotic protein. Pharmacol. Res. 2020, 151, 104547. [CrossRef] [PubMed]

54. Chen, M.; Guerrero, A.D.; Huang, L.; Shabier, Z.; Pan, M.; Tan, T.-H.; Wang, J. Caspase-9-induced mitochondrial disruption through cleavage of anti-apoptotic BCL-2 family members. J. Biol. Chem. 2007, 282, 33888-33895. [CrossRef]

55. Chenal, A.; Dartevelle, S.; Nato, F.; Almunia, C.; Marquette, C.; Gonneaud, A.; Garcia, E.; Forge, V. Production et caractérisation d'anticorps monoclonaux spécifiques de la conformation amyloïde de la protéine Bcl-XL in vitro et in vivo. Applications à la détection de fibres amyloïdes in vivo après stress apoptotique et au criblage de molécules régulatrices de l'amylö̈dogenèse in vitro. Invention deposit at the National Collection of Microorganism Culture of the Institut Pasteur. n ${ }^{\circ} \mathrm{CNCM}-30032.1110,2012$.

56. Yang, T.; Zhu, Z.; Yin, E.; Wang, Y.; Zhang, C.; Yuan, H.; Zhang, H.; Jin, S.; Guo, Z.; Wang, X. Alleviation of symptoms of Alzheimer's disease by diminishing A $\beta$ neurotoxicity and neuroinflammation. Chem. Sci. 2019, 10, 10149-10158. [CrossRef]

57. Faller, P.; Hureau, C.; La Penna, G. Metal ions and intrinsically disordered proteins and peptides: From Cu/Zn amyloid-beta to general principles. Acc. Chem. Res. 2014, 47, 2252-2259. [CrossRef]

58. Bader, B.; Nubling, G.; Mehle, A.; Nobile, S.; Kretzschmar, H.; Giese, A. Single particle analysis of tau oligomer formation induced by metal ions and organic solvents. Biochem. Biophys. Res. Commun. 2011, 411, 190-196. [CrossRef] 
59. Uversky, V.N.; Li, J.; Fink, A.L. Metal-triggered structural transformations, aggregation, and fibrillation of human alpha-synuclein. A possible molecular NK between Parkinson's disease and heavy metal exposure. J. Biol. Chem. 2001, 276, 44284-44296. [CrossRef]

60. Cheignon, C.; Tomas, M.; Bonnefont-Rousselot, D.; Faller, P.; Hureau, C.; Collin, F. Oxidative stress and the amyloid beta peptide in Alzheimer's disease. Redox Biol. 2018, 14, 450-464. [CrossRef]

61. Vardaki, I.; Sanchez, C.; Fonseca, P.; Olsson, M.; Chioureas, D.; Rassidakis, G.; Ullén, A.; Zhivotovsky, B.; Björkholm, M.; Panaretakis, T. Caspase-3-dependent cleavage of Bcl-xL in the stroma exosomes is required for their uptake by hematological malignant cells. Blood 2016, 128, 2655-2665. [CrossRef]

62. Chiti, F.; Dobson, C.M. Protein Misfolding, Amyloid Formation, and Human Disease: A Summary of Progress Over the Last Decade. Annu. Rev. Biochem. 2017, 86, 27-68. [CrossRef] [PubMed]

63. Köhler, G.; Milstein, C. Continuous cultures of fused cells secreting antibody of predefined specificity. Nature 1975, 256, 495-497. [CrossRef] [PubMed]

Publisher's Note: MDPI stays neutral with regard to jurisdictional claims in published maps and institutional affiliations.

(C) 2020 by the authors. Licensee MDPI, Basel, Switzerland. This article is an open access article distributed under the terms and conditions of the Creative Commons Attribution (CC BY) license (http://creativecommons.org/licenses/by/4.0/). 